of the views and proposals of H.M. Forestry Commission on Post-War Forestry Policy in this Country". It is difficult to appreciate the reason for the above statement.

The Imperial Forestry Institute is an Empire organization, or at its inauguration was intended as such. Practically the whole of the forest wealth of the Empire is outside the British Isles and must remain so for many years to come. Research work is presumably one of the important branches of the Institute, and it would appear reasonable that closer co-operation in such work would be at least as necessary as with the Forestry Commission, which is so stressed in the report. Moreover, there are other universities with forest departments ready to undertake research work in collaboration with the Forestry Commission; but there is only one Imperial Forestry Institute, and that is situated at Oxford.

The suggestion for raising the status of the Institute from a pass to an honours school is a wise and farsighted move.

The only students under instruction during the year were the Colonial forestry scholars, four attending the Institute, two of whom were forestry graduates. There was also one candidate for B.Sc., and one for D.Phil. working under the supervision of the professor of forestry.

\section{A NEW MEXICAN VOLCANO}

$\mathrm{P}$ D. TRASK has recently given a preliminary 1 account of the inception and growth of a new volcano, El Parícutin, situated about two hundred miles due west of Mexico City (Trans. New York Acad. Sci.; Dec. 1943).

Prof. L. C. Graton, professor of mining geology at Harvard, spent nearly two months in the region making trips to it and flying over it twice; and he describes its growth in Sky and Telescope of February. A well-illustrated article on the volcano also appears in the National Geographic Magazine of February 1944.

The first intimation of awakening activity was the occurrence in February 1943 of numerous earthquakes in the district. On February 19 some three hundred shocks were reported. The next day a Tarascan Indian farmer was astonished to see 'smoke' spiralling up from a hole in a field which he was ploughing.

That night the first explosion occurred, and since then-at least up to the end of the year-the volcano has been erupting steadily. Within a week the cone reached a height of $550 \mathrm{ft}$. and by late September it had grown to $1,500 \mathrm{ft}$. During the early days explosions in quick succession expelled a cylindrical column of ash which, after reaching a height of some hundreds of feet, suddenly formed dark expanding clouds that billowed up to $6,000-8,000 \mathrm{ft}$., when steam began to condense, after which the ash cloud became progressively whiter until it passed into a horizontal cloud of curling puffs of vapour at about $15,000-18,000 \mathrm{ft}$. Later on, much of the fragmental material consisted of red-hot bombs, blown $2,000-3,000 \mathrm{ft}$. into the air. A cone $100 \mathrm{ft}$. high was built up in the course of the first day.

Two days after the birth of the volcano, lava emerged from a field about a quarter of a mile from the crater and continued to flow for six weeks, by which time it was more than a mile long and $100 \mathrm{ft}$. thick. Early in June eight lava flows issued from the cone itself. The crater at this time was occupied by lava to within $50 \mathrm{ft}$. of the rim, and through the congealed blocky surface ashes were being erupted. It was observed that each flow was preceded by a phase of violent explosive activity, but that while lava was actually escaping, explosions were relatively few. By September several other flows had broken through the flanks of the cone. The lava consists of andesitic basalt of essentially the same type as that erupted by the hundreds of older and now apparently extinct volcanoes that occur within a radius of about seventyfive miles around Parícutin.

It is of interest that the only previous volcanic activity in the region, within the memory of man, occurred in 1759 when the celebrated new volcano of Jorullo suddenly appeared, some fifty miles to the south-east of Parícutin, and built a 1,000-ft. cone in five months of activity.

\section{NATIVE RESERVES IN SOUTH AFRICA}

$\mathrm{T}$ HE Native Reserves provide homes for one third of the South African population, and constitute the chief source of labour for mines and industries. Soil wastage, resulting from over-stocking and primitive methods of agriculture, is rapidly converting the reserves into deserts. A memorandum, drawn up at the suggestion of the Cape Town Branch of the Association of Scientific Workers of Southerm Africa, puts forward a comprehensive scheme of reorganization*.

A start might be made in the following terms with certain limited areas, and the new system gradually extended until it covers the entire Reserves. (1) An ecological survey of the given area; (2) the area to be fenced and made into suitable paddocks for summer and winter grazing; (3) all serub bulls to be culled and the necessary number of good bulls to be provided; (4) progressive limitation of cattle to the estimated carrying capacity of the land. It would be a good thing to regard each area as a collective farm, and each communal farm should have a communal centre with offices, hall for meetings and lectures, perhaps a school building, barns and silos, sheds for storage, ete. An African agricultural officer, as general adviser, should be stationed at each farm. Families would be entitled to their own plots of arable land fenced off from the communal land. Though encouraged to store and market collectively, the individual peasant would be entitled to the products of his own land, and individual ownership of cattle would have to be tolerated. All able-bodied members of the commune would be expected to provide a minimum amount of labour under the management of a committee. Technical training schemes would also be desirable.

It is realized that certain major changes in South African governmental policy-improvement in. the social and commercial conditions of Africans outside the Reserves and provision of more land and industrial opportunities within-must accompany any serious attempt to deal with the general problem.

K. L. LitTite.

* Association of Scientifle Workers of Southern Africa. Research Memorandum, No. 3. The Native Reserves and Post-War Reconstruction. By Edward R. Roux. (Cape Town.) $6 d$. 